\title{
Study on the Development Strategy of Shandong Home Stay From the Perspective of Local Culture
}

\author{
Yan $\mathrm{Liu}^{1 *}$ \\ ${ }^{1}$ Shandong Women's University, Tourism Institute, Jinan, Shandong, China
}

\begin{abstract}
Rural home stay is not only a popular tourist accommodation products but also an important carrier of local culture. In recent years, rural home stay has shown a well-developed trend as the State vigorously develops rural tourism. Starting with the study of the theory of home stay, this paper, on the basis of analyzing the connotation of the local culture and the local culture of home stay, focuses on the characteristics of Shandong local culture, and forms the products of home stay with different characteristics, interdependence and complementarity through effective integration, so as to promote the cluster and sustainable development of Shandong home stay industry.
\end{abstract}

\section{Introduction}

Under the background of the development of tourism in the whole region, the countryside has become the best carrier to undertake the demand of the quality-oriented leisure vacation for the city residents. The tourists' demand for rural home stay has changed qualitatively. As the combination of local culture and rural experience, home stay can satisfy people's desire for rural feelings. Local culture is the core element of the sustainable development of the home stay industry in the future. At present, there are still a lot of problems in the development of the Shandong home stay, and moreover, the sudden outbreak of the COVID-19 epidemic in 2020 has brought a series of negative effects to the home stay industry. It is of great significance to put the essence of the local culture into the development in Shandong home stay and to integrate the local cultural resources.

\section{Connotation of local culture of home stay}

\subsection{The concept of home stay}

In July 2019, the Ministry of Culture and Tourism issued the "Basic Requirements and Evaluation of Tourism home stay" which pointed out that: Tourism home stay refers to the small accommodation facilities which use local residential and other related idle resources, its operating rooms are no more than 4 floors, construction area is no more than 800 square meters, and its owner participates in the reception to provide the experience of the local natural, cultural and production lifestyle for tourists. According to the geographical differences, it can be divided into urban home stay and rural home stay. This article is to study the category of the rural home stay.

\subsection{The connotation and composition of local culture}

\subsubsection{The connotation of local culture}

At present, the industry more widely cites Mr. Xiaotong Fei's point of view, he pointed out that "China's traditional culture is a local culture." Through the review of the literature, the local culture can be divided into two levels: material and spirit. The local culture at the material level is the special material resources formed under the geographical condition, including the natural scenery of the countryside, the building of the house and so on; the local culture at the spiritual level is the cultural resources formed in the special area after many years' development, including folk customs, traditional techniques, fairy tales and so on. From the perspective of the development of rural tourism, this paper uses the former definition to understand the meaning of local culture: "The unique and relatively stable cultural form and knowledge system formed in the long-term common life in the countryside".

\subsubsection{Constitution elements of local culture}

Through the in-depth analysis of the connotation of local culture, we can see that the main elements of local culture include natural landscape, folk buildings, ancient trees and famous trees, production modes, folk customs, myths and legends, traditional techniques, village rules and conventions, etc. (see Table 1) 
Table1. Constitution Elements of Local Culture

\begin{tabular}{|c|c|c|}
\hline Level & $\begin{array}{c}\text { Constitution } \\
\text { Elements }\end{array}$ & Connotation of Local Culture \\
\hline \multirow{3}{*}{$\begin{array}{l}\text { Material } \\
\text { level }\end{array}$} & $\begin{array}{c}\text { Natural } \\
\text { landscape }\end{array}$ & $\begin{array}{l}\text { The landscape which is less affected } \\
\text { by human and its original natural } \\
\text { features did not change significantly. }\end{array}$ \\
\hline & Civil building & $\begin{array}{l}\text { Residential houses with local } \\
\text { characteristics in style and type } \\
\text { influenced by geographical } \\
\text { conditions and lifestyle. }\end{array}$ \\
\hline & $\begin{array}{l}\text { Ancient trees } \\
\text { and famous } \\
\text { trees }\end{array}$ & $\begin{array}{l}\text { The old trees that have been growing } \\
\text { for more than a hundred years or have } \\
\text { social influence and are world- } \\
\text { famous, and are of high artistic } \\
\text { appreciation value. }\end{array}$ \\
\hline \multirow{5}{*}{$\begin{array}{l}\text { Spiritual } \\
\text { level }\end{array}$} & $\begin{array}{l}\text { Mode of } \\
\text { production }\end{array}$ & $\begin{array}{l}\text { The way that human beings seek the } \\
\text { basic material information of social } \\
\text { life and the foundation of human } \\
\text { society's existence and development. }\end{array}$ \\
\hline & Folk custom & $\begin{array}{l}\text { The habits and customs that local } \\
\text { people follow together under the } \\
\text { influence of culture and values. }\end{array}$ \\
\hline & $\begin{array}{l}\text { Fairy tale and } \\
\text { legend }\end{array}$ & $\begin{array}{l}\text { Fantasy-colored folklore, including } \\
\text { historical events, mythological } \\
\text { figures and local style stories. }\end{array}$ \\
\hline & $\begin{array}{l}\text { Traditional } \\
\text { technique }\end{array}$ & $\begin{array}{l}\text { The local unique and distinctive skills } \\
\text { and technique which reflect the } \\
\text { heritage of local culture. }\end{array}$ \\
\hline & $\begin{array}{l}\text { Village rules } \\
\quad \text { and } \\
\text { regulations }\end{array}$ & $\begin{array}{l}\text { The behavior and ethics which are } \\
\text { observed jointly by the village } \\
\text { residents in accordance with the laws } \\
\text { and regulations of the state, clan } \\
\text { rules, family style, etc. }\end{array}$ \\
\hline
\end{tabular}

\subsection{Local culture connotation of home stay}

\subsubsection{Localism of the space location of home stay}

Home stay is a kind of experience to the rural life style and the rural life attitude, from the course of the development of the industry, no matter at home or abroad, home stay is born in the countryside, especially in the countryside or the suburbs rich in natural resources, so home stay has obvious local characteristics in the spatial location. The regional culture brought by the rural space location in which the home stay locates in is the core competitiveness of the rural home stay.

\subsubsection{Localism of the material and spiritual form of home stay}

The localism of the material level of home stay is usually reflected in the local natural scenery, residential buildings and so on. Most of the rural home stay is rebuilt on the basis of the local idle dwellings, and the design is inspired by the state of life in the countryside, so the rural buildings with strong local characteristics visually transmit different local cultures. The localism of the spiritual level of home stay is usually reflected in the local production mode, folk custom and so on, and the simple folk customs are the core attraction of home stay products. Because the home stay is a small personalized accommodation product, it usually combines with local characteristics of culture to design the theme in terms of the design of products, back to the natural and simple way of life, and arouse tourists' nostalgia from the spirit and emotion.

\subsubsection{Localism of the operators of home stay}

From the point of view of our country's home stay investors, there are mainly two types: local developers and foreign developers. Local developers mostly have the experience of studying or working in other places and come back to start a business, this group has a strong sense of local cultural identity, in the process of learning or working outside, they realized that the familiar members and love of local cultural elements have become the yearning and pursuit of modern urban people, so the local cultural complex from the bottom of the heart is gradually strengthened, forming an unconscious cultural selfconscious behavior. Most of the non-resident developers of home stay are urban elites with good economic foundation. They are tired of the hustle and bustle of the city and yearn for the quiet and simple rural life. They hope to realize their own life ideal and career success through the management of the home stay, so they often show their strong attachment to the local culture.

\section{Fusion and Expression of home stay to Local Culture}

\subsection{The return and inheritance of home stay to local culture}

The houses, articles of daily use and tools of production on which home stay depends on have obvious local colors. These rural memories come into the tourists' lives as cultural elements, which can arouse people's nostalgia and longing for the local culture. Supported by the village's natural scenery, village layout, customs and other elements, a complete local landscape is built. At the same time, home stay is an important carrier of non-material culture in the countryside, and it is also an important embodiment of the deep local feelings of home stay, relying on the face-to-face communication between home stay operators and tourists, the sharing of their own life experiences and the interpretation of the local human ecology to create a harmonious host - guest relationship and to create a "family" atmosphere.

\subsection{The development and innovation of home stay to local culture}

Local culture is the foundation of Chinese civilization. Through deep excavation and interpretation of local culture, integrating modern art means, integrating all kinds of resources and presenting them in the form of home stay products, it can not only meet the needs of tourists for local culture experience, but also make traditional culture develop. In addition, home stay can also innovate on the basis of inheriting the local tradition, such as introducing new materials and new technology into the construction of the residence, trying to combine traditional forms with modern means in service, improving the forms of singing and dancing and performing techniques in tourist experience links. The development and innovation of the local culture is the infinite source of the development of the home stay 
industry.

\subsection{The construction of home stay to the post- local culture}

The integration and interaction of local culture and modern civilization will lead to the reconstruction of local culture. For example, in Taiwan, some rural tourism practitioners put the comfort of modern civilization into the nature of rural life, and constructed a "poetic countryside" which the modern urban people yearn for in order to escape the pressure of life, known in Taiwan as the "post-village". "At present, the local culture is going through an unprecedented process of change, which happened with the transformation of the whole Chinese society." In recent years, the rising high-end home stay is the result of the local culture reconstruction under the interaction between the local culture and modern civilization.

\section{Current Situation of home stay in Shandong}

\subsection{The development status of home stay in Shandong}

In order to ensure the healthy development of Shandong home stay, the government and related departments have issued a number of policies to protect and escort the development of home stay. In May 2017, Shandong Provincial Tourism Development Committee issued the "Classification and Evaluation of the Service Quality of Homestead in Shandong", which standardized the basic conditions, service requirements and grading criteria for the development of home stay. In March 2020, 14 departments such as Shandong Provincial Department of Culture and Tourism jointly issued the "Guiding Opinions on Promoting the High Quality Development of Tourism home stay", and put forward that by 2022, there will be more than 500 three-star tourism home stay, more than 160 four-star tourism home stay, and 16 large-scale tourism home stay agglomeration areas to form the national leading tourism home stay pattern with standardized management and first-class service.

At present, Shandong is making efforts to create a home stay brand series leading by "hospitable family", so as to enhance the attraction and influence of the Shandong home stay. As of September 30, 2019, there were 169,800 home stay in Mainland China, while 10,639 in Shandong was ranked fifth in the country in total, according to the "Report on the Development of China's Tourism home stay (2019)". In addition to the rapid growth in quantity, Shandong home stay began to move towards high-end and boutique direction. In 2017, Shandong Provincial Tourism Development Committee and Shandong Provincial Finance Department issued official documents, selected 6 five-star boutique home stay in the province. At the same time, more and more high-quality boutique home stay conveys strong feelings of the countryside to people in different ways.

\subsection{Problems in the development of home stay in Shandong}

\subsubsection{Insufficient digging of the connotation of local culture}

Along with the development of the rural home stay, some of the home stay management institutions are driven by the benefits. In order to improve occupancy rate and increase economic benefits, some institutions copy the traditional hotel design concept, and neglect the local color and personalized characteristics of the home stay. In addition, part of the villagers' self-employed extensive "Agritainment" cannot fully explain the connotation of local culture. The native villagers have a unique emotion to the native culture, however, due to the lack of reasonable planning and professional guidance, villagers' spontaneous management often can only convey their understanding of "local culture" through the most primitive way. Such home stay is often difficult to satisfy tourists' pursuit of rural life and local feelings.

\subsubsection{Serious homogenization of products}

From the current situation of Shandong home stay, most of the home stay's market location is not clear, lacking of characteristics and creativity, and imitation of others practices abounds. Especially in the same area or neighboring villages, whether the building style or the food and lodging products often have higher similarity. There is a strong substitutability between the home stay products, and there is also a great arbitrariness in the process of tourists' choice. The homogenization of products leads to the confusion of the home stay market competition and the inadequacy of sustainable development.

\subsubsection{The lower degree of clustering}

Most of home stay is owned by villagers, belonging to joint ventures or foreign investors. This kind of disorder condition makes the home stay management loose in many places, and it can't converge to form a certain scale, the influence is relatively small. From the experience of home stay development in China, it is necessary to form large-scale community of home stay and take the road of cluster development. However, home stay in many areas of Shandong is still in the state of fighting alone, and there are such common problems as scattered distribution, traffic inconvenience and small volume. In the future, the main direction of the development of the home stay industry is the confluence of home stay brands, unified planning and design, and complete facilities. 


\section{Suggestions for Shandong home stay from the Perspective of Local Culture}

\subsection{Actively implement policies and give play to the leading role of the government}

The government's leading role plays an important role in the protection and inheritance of local culture. First of all, local governments should strengthen communication with local residents, fully understand the wishes of indigenous people, brainstorm, tap the essence of local culture from the masses, and use it in management. Second, support academic research and its achievement promotion, interpret local culture from the root, and guide from a scientific point of view. Third, guide local people to build cultural self-confidence and encourage local residents to participate in the interaction with tourists, so that their enthusiasm and sense of responsibility towards protecting and inheriting the local culture are stimulated when they can get economic benefits.

\subsection{Integrate local culture to construct home stay clusters}

As a major agricultural province in China, Shandong has gestated a variety of local culture. Based on rich cultural resources, Shandong home stay can create the overall image of region home stay, refine local culture design symbols, and plan the unified brand with distinctive characteristics from the perspective of regional cultural characteristics through the planning guidance of the government and professional institutions, integrating regional cultural resources, and after effective integration, it is launched into the market to form the home stay brand with a strong attraction and the regional characteristics. In the future, we will strengthen the cultural co-construction from the angle of cluster development, and form a complementary tourism home stay cluster with reasonable scale and unified image to provide the competitiveness of Shandong home stay.

\subsection{Pay attention to spiritual edification and enrich cultural connotation}

At present, the transmission of local culture by Shandong home stay mostly stays at the material level, but it cannot fully satisfy the tourists' deep search for local culture only through these materials. In the next step, we should give full play to the important role of traditional culture in edifying sentiment and cultivating aesthetic idea, and then engage at the spiritual level. Actively arouse local villagers to offer ideas and suggestions, carry out some pleasant cultural recreational activities in the home stay, carry forward the valuable intangible cultural heritage in the local culture, and arouse people's consciousness of protecting rural culture and inheriting traditional art.

\subsection{Incorporate technology to improve tourists' experience}

In the future, high-quality home stay will be developed towards low-key luxury, and the use of high-tech means is imperative. In the post-epidemic era of COVID-19, the science and technology is applied to improve the experience of service, and ensuring the health and safety of tourists. In the future, the application of artificial intelligence, big data, cloud computing, 5G network and other technologies in the development of home stay will certainly push the development of home stay in Shandong towards intelligence, science and technology and highend direction.

\section{Conclusion}

This paper, starting with the connotation of the home stay culture, analyzes the local characteristics of Shandong home stay and studies how to better meet the individual needs of tourists by promoting the expression of the local culture products of the home stay. In the post-epidemic era, the recovery and sustainable development of Shandong home stay in economic benefit, ecological protection and local culture inheritance are realized.

\section{Acknowledgments}

This paper is one of the achievements of the "Research on the Development of Shandong home stay Cluster under the Perspective of Local Culture" which is the key subject of art science in Shandong Province in 2020.

\section{References}

1. Xi Zhang. The Expression of Local Culture in home stay: Regression and Construction [J]. Journal of Minjiang University, 2016, 37 (03): 114 - 121.

2. Guanhua Huang. A study on the construction and expression of local culture in residential development [J]. Beijing Agricultural Vocational College Journal, 2020, 34 (03): 12 - 18.

3. Yueqi Fang. An Empirical Study on Rural Tourism Development Based on Local Culture-A Case Study in Honghu Tea Village, Hubei Province [D]. Central China Normal University Master Thesis, 2019.

4. Zhengyong Yu, Xing Chen, Lei Li, Qi Mao. Construction of evaluation index system of home stay for rural cultural inheritance and innovation [J]. Journal of Sichuan Institute of Tourism, 2020 (06): 81 $-86$. 